\title{
VERIFICATION OF HPLC FOR THE QUANTITATIVE DETERMINATION METHOD OF NIFEDIPINE IN TABLETS
}

\author{
I.L.Komarytskyy, V.A.Khanin, N.Yu.Bevz, V.A.Georgiyants \\ National University of Pharmacy \\ Key words: nifedipine; verification; HPLC
}

Currently a great number of generic drugs have been registered in Ukraine. The advantage of generic drugs is a relatively low cost compared to innovative medicines since creation and registration of generics require less research and, consequently, less material costs for development, research and market penetration of a new drug. Because of creation of the second edition of SPhU and inclusion of articles on the finished products, we have set ourselves the goal to analyze the validation characteristics of the quantitative chromatographic determination of nifedipine in tablets and to verify the analytical procedure. Linearity of the method was determined in the range of $80-120 \%$ of the nominal concentration. Linearity of the method has been confirmed within the whole range of concentrations studied $(b=1.0031$, $\left.S_{b}=0.0007816, a=-0.11, S_{a}=0.07891, S_{0}=0.03055, r=1.0000\right)$. It has been proven that the method suggested is characterized by sufficient convergence and accuracy over the entire range of concentrations $\left(\Delta_{z}=0.06, \delta \%=0.2\right)$. The intermediate precision has been confirmed by the fact that the value of the relative confidence interval for five parallel measurements of one batch of the drug meets the acceptance criterion ( $\Delta z=0.22 \% \leq 1.6 \%)$. Thus, according to the results of determining the validation characteristics of the methods for quantitative determination it has been substantiated and experimentally proven that this analytical procedure can be correctly reproduced, gives accurate results and is suitable for the analysis of nifedipine tablets. In the process of verification of the method for quantitative determination of nifedipine in tablets such validation characteristics of the chromatographic method as accuracy, linearity, precision, specificity and intermediate precision have been studied. The validation characteristics of the method do not exceed the critical value of error (1.6\%) and are characterized by qualitative analytical indicators. This method can be correctly reproduced in the laboratory conditions.

Nifedipine is the main representative of calcium antagonists, derivatives of 1,4-dihydropyridine, which is widely used in medical practice. It blocks voltage-dependent calcium channels and prevents the penetration of calcium ions into smooth muscle cells of blood vessels. Nifedipine lowers blood pressure, improves the coronary blood flow, and exhibits the anti-anginal, hypolipidemic and antisclerotic effect. It is produced in the form of powder, solution for injections, capsules, tablets, ointment, drops and other medicinal forms [5].

The scientific literature describes methods for quantitative determination of nifedipine by cerimetric titration in the non-aqueous medium [8] and HPLC [13, 16, 17], voltammetry [12, 14], polarography [7] and UV spectrophotometry $[1,6,10]$. Besides, the method of highly sensitive kinetic determination of nifedipine using the luminol-persulfate chemiluminescence system is known [11]. For the quantitative determination of nifedipine USP37-NF32 [15] the use of the method of liquid chromatography is recommended.

Because of creation of the second edition of SPhU and inclusion of articles on the finished products, we have set ourselves the goal to analyze the validation characteristics of the quantitative chromatographic determination of nifedipine in tablets and to verify the analytical procedure.

\section{Materials and Methods}

When conducting the research the substance of nifedipine meeting the SPhU requirements was used.
The following analytical equipment was used: a 2695 chromatograph with a 2996 diode matrix detector of Waters Corp. firm, USA; XTerra RP18 column $250 \times 4.6 \mathrm{~mm}$ with the particle size of $5 \mu \mathrm{m}$, a ER-182 balance of AND company, Japan; glassware for measuring of class A.

We made a chromatogram of standard sample (SS) solution receiving from 2 to 6 chromatograms. The injection volume was $25 \mathrm{ml}$. The relative standard deviation (RSD) was calculated for peak areas of the chromatograms obtained. Chromatography $\left(\mathrm{n}_{0}\right)$ was discontinued when reaching the values (RSD) specified in the requirements for suitability of the chromatographic system.

Chromatography was performed on a liquid chromatograph with a UV detector under the following conditions:

- mobile phase: acetonitrile for chromatography - methanol - water (25:25:50) degassed by ultrasound;

- detection: at the wavelength of $265 \mathrm{~nm}$;

- the rate of the mobile phase: $1.0 \mathrm{ml} / \mathrm{min}$.

Preparation of Test Solution

Place 5 tablets in a $50 \mathrm{ml}$ volumetric flask, add $40 \mathrm{ml}$ of the mobile phase, shake for 20 minutes, dilute to the volume with the mobile phase, mix and filter through a glass filter.

Preparation of SS solution

Place $20 \mathrm{mg}$ of nifedipine USP RS in a $20 \mathrm{ml}$ volumetric flask, add $10 \mathrm{ml}$ of the mobile phase, shake to dissolve and dilute to the volume with the mobile phase, mix and filter through a glass filter. 


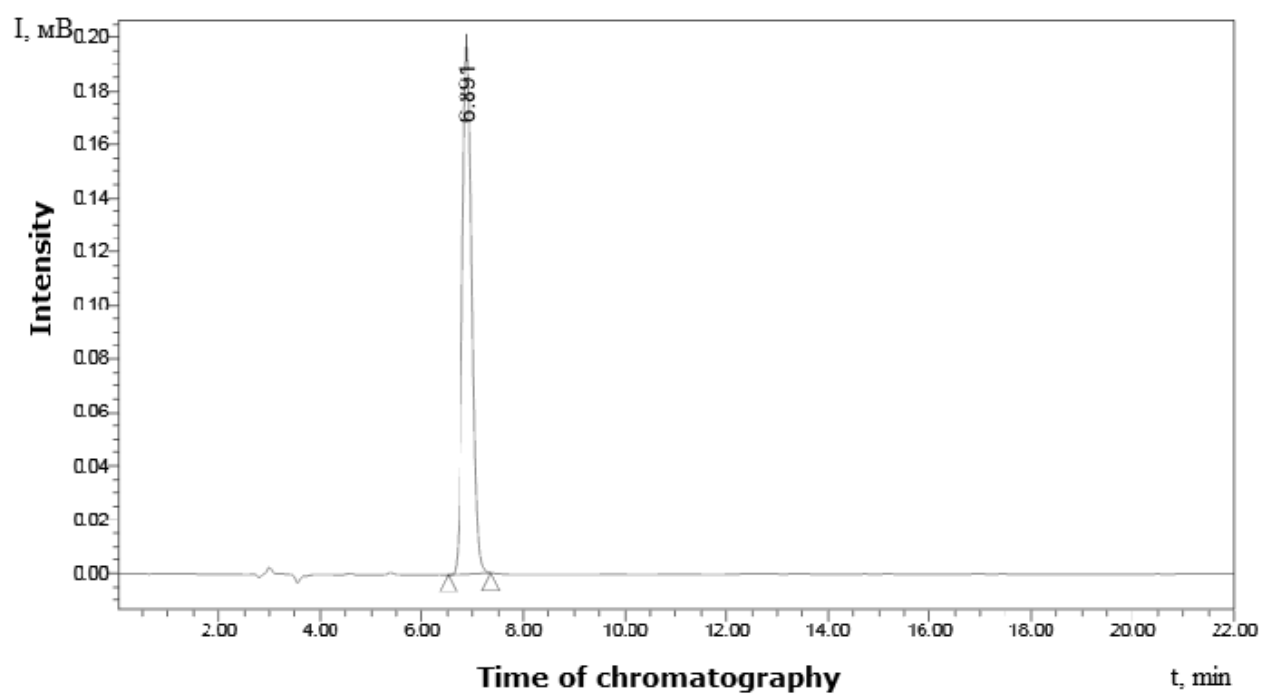

Fig. 1. The chromatogram of the Standard solution of nifedipine.

Before the main tests were validated, the presence of documents certifying the suitability of the equipment, raw material and chemicals was controlled.

Validation of the method was carried out in accordance with the requirements of the SPhU [2-4].

\section{Results and Discussion}

For elaboration of the method the chromatograms of the Standard solution of nifedipine (Fig. 1) and the Test solution of nifedipine (Fig. 2), as well as the dependence of the intensity peaks on the retention time were obtained and analysed.

The results of the analysis are considered reliable if the requirements of the System Suitability Test are performed. The chromatographic system is considered suitable if the following conditions are performed:

- the effectiveness of the chromatographic column calculated by the peak of nifedipine in the chromatogram of nifedipine SS must be not less than 4000 theoretical plates;

- the peak symmetry factor calculated by the peak in the chromatogram of nifedipine SS should be from 0.8 to 1.5 ;
- the relative standard deviation (RSD) for peak areas of nifedipine from the chromatogram obtained with the reference solution for 3 parallel measurements should be not less than $1.0 \%$.

Our results of quantitative determination of nifedipine in the drug according to the method indicate its reproducibility.

Verification of the method for quantitative determination of nifedipine in tablets was performed by such validation characteristics as specificity, linearity, convergence, precision, accuracy and the intermediate precision.

To assess the accuracy of the sample preparation of the model solutions and standard sample solution the theoretical uncertainties of the analytical procedure that was $\Delta_{\mathrm{sp}}=1.07 \% \leq \mathrm{B} \cdot 0.32=1.6 \%$ were calculated. Thus, the uncertainty of sample preparation calculated and analysis in general should provide sufficient accuracy.

Since high performance liquid chromatography (HPLC) used in the method is specific, then to prove that the method is specific it is sufficient to perform all requirements of the criteria for linearity, accuracy, precision and the intermediate precision.

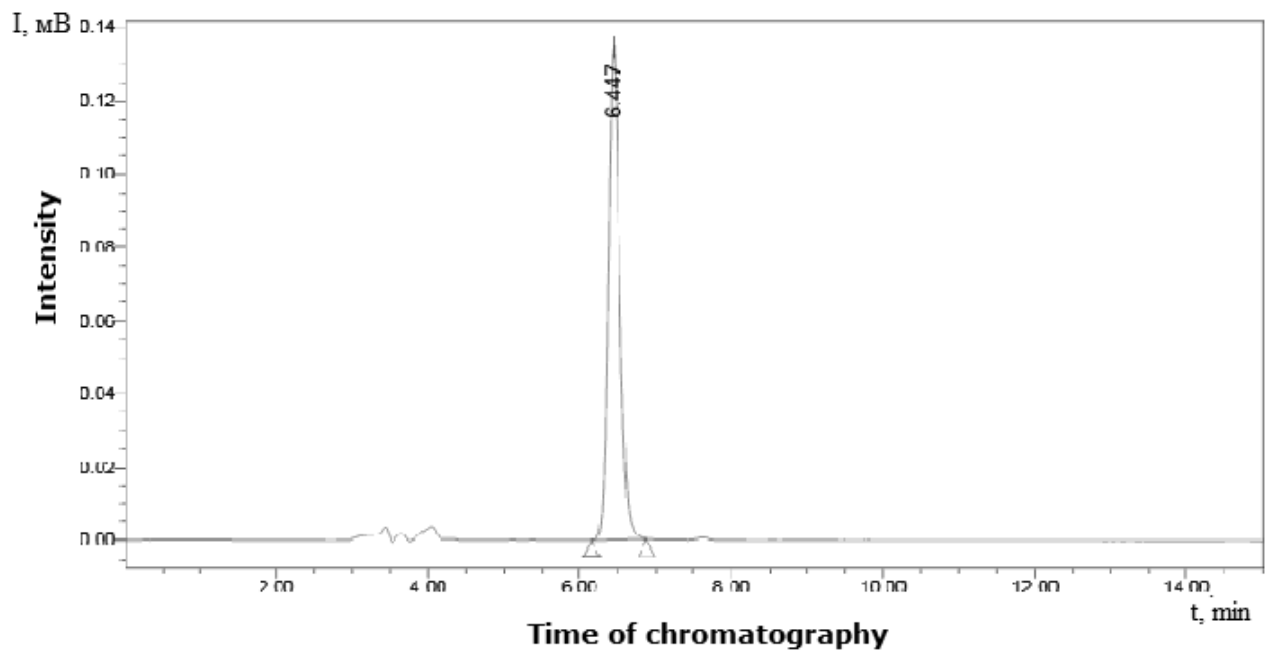

Fig. 2. The chromatogram of the Test solution of nifedipine. 


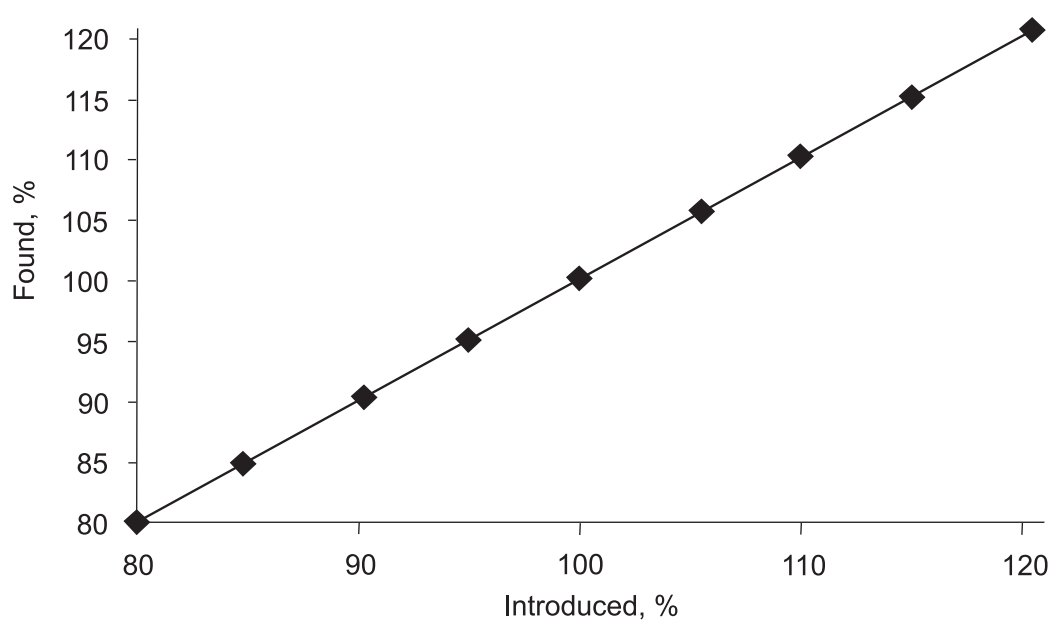

Fig. 3. The linear dependence of the peak area on the concentration of nifedipine in normalized coordinates.

Solutions for chromatography were prepared by the methods listed.

Evaluation of linearity was performed on the entire range of application of the method using the standard method. The study of dependence of absorbance on the concentration was conducted using 9 model solutions for analysis of the sample concentrations accurately weighed: $80,85,90,95,100,105,110,115$ and $120 \%$.

The results obtained were statistically processed by the least squares method according to the requirements of the SPhU. The calibration graph was constructed in normalized coordinates (Fig. 3). For each of the nine test solutions the average values of the peak area $\left(S_{i}\right)$ were calculated. The results obtained were processed by the least squares method for line $Y=b \times x+a$ (Fig. 3). The statistical quantities $b, S_{b}, a, S_{a}, S_{r}$ (final standard
Table 1

Characteristics of the linear dependence

\begin{tabular}{|l|c|}
\hline The slope of the linear relationship $b$ & 1.0031 \\
\hline$S_{b}$ & 0.0007816 \\
\hline The constant term of the linear dependence $a$ & -0.11 \\
\hline$S_{a}$ & 0.07891 \\
\hline The residual standard deviation $S_{r}$ & 0.03055 \\
\hline The correlation coefficient method $r$ & 1.0000 \\
\hline
\end{tabular}

deviation) calculated and $r$ (correlation coefficient) are shown in Fig. 3 and in Table 1.

Requirements for the parameters of the linear dependence in this case are carried out within the whole range of the method application (80-120\%).

Table 2

The results of analysis of model solutions and their statistical analysis

\begin{tabular}{|c|c|c|c|c|}
\hline $\begin{array}{l}\text { No. of the } \\
\text { model } \\
\text { solution }\end{array}$ & $\begin{array}{l}\text { Introduced in } \% \text { to the } \\
\text { concentration of the } \\
\text { reference solution } \\
\left(X_{i}=C_{i} / C_{s t} \%\right)\end{array}$ & $\begin{array}{l}\text { Average peak areas }\left(S_{i}\right) \\
\quad\left(S_{s t}=1395946\right)\end{array}$ & $\begin{array}{l}\text { Found in } \% \text { to the } \\
\text { concentration of the } \\
\text { reference solution } \\
\left(Y_{i}=S_{i} / S_{s^{t}} \%\right)\end{array}$ & $\begin{array}{l}\text { Found in } \% \text { to the } \\
\text { introduced } \\
\left(Z_{i}=Y_{i} / X_{i} \%\right)\end{array}$ \\
\hline 1 & 80.00 & 1117874 & 80.13 & 100.16 \\
\hline 2 & 84.75 & 1223965 & 84.93 & 100.22 \\
\hline 3 & 90.25 & 1309677 & 90.39 & 100.16 \\
\hline 4 & 95.00 & 1346390 & 95.20 & 100.21 \\
\hline 5 & 100.00 & 1375007 & 100.22 & 100.22 \\
\hline 6 & 105.50 & 1465743 & 105.68 & 100.17 \\
\hline 7 & 110.00 & 1535541 & 110.26 & 100.24 \\
\hline 8 & 115.00 & 1612457 & 115.28 & 100.25 \\
\hline 9 & 120.50 & 1669691 & 120.74 & 100.20 \\
\hline & & & Mean, Z, \% & 100.20 \\
\hline \multicolumn{4}{|c|}{ Relative standard deviation, $R S D_{z^{\prime}} \%$} & 0.0324 \\
\hline \multicolumn{4}{|c|}{ Relative confidence interval, $\Delta Z(\%)=t(95 \%, n-1) \times R S D_{Z}=1.860 \times R S D_{Z}, \%$} & 0.06 \\
\hline \multicolumn{4}{|c|}{ Critical value for convergence of the results $\triangle A s, \%$} & 1.6 \\
\hline \multicolumn{4}{|c|}{ Systematic error $\delta=|Z-100| \mid$} & 0.2 \\
\hline \multicolumn{4}{|c|}{$\begin{array}{r}\text { Criterion of the systematic error insignificance } \\
\text { 1) } \delta \% \leq 1.03 / 3=0.34(0.20>0.348) \\
\text { isfied 1), then } \delta \% \leq 0.32 \times 1.6=0.51 \%(0.20<0.51)\end{array}$} & $\begin{array}{l}\text { is not satisfied } \\
\text { satisfied }\end{array}$ \\
\hline \multicolumn{4}{|c|}{ The overall conclusion of the procedure } & correct \\
\hline
\end{tabular}


To measure and calculate the metrological evaluation of convergence and accuracy of the method three values of peak areas for the reference solution and 27 values of peak areas for model solutions were obtained. The actual values $\left(X i_{a c t}\right)$, the ratio of the average values of peak areas for each of 27 solutions were calculated to the mean peak area of the reference solution, the values $X_{i}=\left(C_{i} / C_{s}\right) \times 100 \%, Y_{i}=\left(S_{i} / S_{s}\right) \times 100 \%$, as well as the value $Z_{i}=\left(Y_{i} / X_{i}\right) \times 100 \%$, the concentration found in $\%$ to the concentration introduced were determined. The calculation results are shown in Table 2.

To assess the intermediate precision the relative confidence interval for 5 parallel measurements of the quantitative content of substances, which should be less than the maximum permissible uncertainty analysis results $\left(\Delta_{Z} \leq 1.6 \%\right)$, was used. Tests were carried out using one batch of the drug by different drug analysts on the same chromatograph in different days using different measuring vessels.

Intermediate precision has been confirmed by the fact that the relative size of the confidence interval for five parallel measurements of one batch of the drug meets the acceptance criterion $\left(\Delta_{\mathrm{Z}}=0.22 \% \leq 1.6 \%\right)$.

\section{CONCLUSIONS}

1. In the process of verification of the method for quantitative determination of nifedipine in tablets such validation characteristics of the chromatographic method as accuracy, linearity, precision, specificity and intermediate precision have been studied.

2. The validation characteristics of the method do not exceed the critical value of error (1.6\%) and are characterized by qualitative analytical indicators. This method can be correctly reproduced in the laboratory conditions, and independent of the excipients.

\section{REFERENCES}

1. Бугрова Е.А., Титова А.В., Арзамасиев А.П. // ХФЖ. - 2000. - №4. - С. 55-56.

2. Гризодуб А.И. // Фармаком. - 2006. - №1/2. - С. 34-44.

3. Держсавна фармакопея Украйни / Державне підприємство «Науково-експертний фармакопейний центр». X.: РІРЕГ, 2001. - 556 c.

4. Держсавна фармакопея Украйни / Державне підприємство «Науково-експертний фармакопейний центр».Доп. 1. - Х.: РІРЕГ, 2004. - 520 c.

5. Компендиум 2009-лекарственные препараты. В 2-х т. / Под ред. В.Н.Коваленко, А.П.Викторова. - К.: МОРИОН, 2009. - 2224 c.

6. Тимошик Ю.В., Петренко В.В. // Фарм. журн. - 2009. - №3. - С. 64-69.

7. Шаповалов В.А. // ЖАХ. - 2002. - №2. - C. 185-186.

8. British Pharmacopoeia. - London: The Stationary Office, 2009. - Vol. 1, 2. - 6481 p.

9. Ćwiczenia z chemii lekow / Pod red. M.Gorczycowej, F.Zejca. - Krakov: Collegium Medium UJ, 1996. - 200 p.

10. Hemmateenejad B., Miri R., Kamali R. // J. Iran. Chem. Soc. - 2009. - №1. - P. 113-120.

11. He Shuhua, Lu Yi, He Deyong et al. // Chin. J. Anal. Chem. - 2004. - №4. - P. 474-476.

12. Madhusudana R.T., Jayarama R.S. // Anal. Lett. - 2004. - №10. - P. 2079-2098.

13. Niopas I., Daftsios A.C. // J. Pharm. and Biomed. Anal. - 2003. - №6. - P. 1213-1218.

14. Nuran O., Ceren Y., Suslu I. // J. Pharm. and Biomed. Anal. - 2002. - №3. - P. 573-582.

15. USP37-NF32 [Електронний ресурс]: - Режим доступy: http://www.usp.org/usp-nf/pharmacopeial-forum.

16. Vertzoni M.V., Reppas C., Archontaki H.A. // Anal. Chim. Acta. - 2006. - №573. - P. 298-304.

17. Yang Bingyi, Mo Jinyuan, Lai Rong et al. // Chin. J. Anal. Chem. - 2004. - №10. - P. 1304-1308.

ВЕРИФІКАЦІЯ ВЕРХ МЕТОДИКИ КІЛЬКІСНОГО ВИЗНАЧЕННЯ НІФЕДИПІНУ В ТАБЛЕТКАХ І.Л.Комарицький, В.А.Ханін, Н.Ю.Бевз, В.А.Георгіяни

Ключові слова: ніфедеипін; верифрікація; ВEPX

У теперішній час час в Україні зареєстровано велику кількість відтворених лікарських засобів (ЛЗ). Перевага відтвореного ЛЗ полягає у відносно невисокій вартості у порівнянні з оригінальним ЛЗ, оскільки його створення і реєстрація вимагають меншого обсягу досліджень i, відповідно, менших матеріальних витрат для розробки, дослідження та впровадження на ринок нового ЛЗ. У зв'язку зі створенням другого видання ДФУ і включенням до неї статей на готові лікарські засоби ми поставили собі за мету проаналізувати валідаційні характеристики методики кількісного хроматографрічного визначення ніфредипіну в таблетках та провести її верифрікацію. Лінійність методики визначали в межах 80-120\% від номінальної концентрації. Лінійність методики підтверджується у всьому діапазоні досліджуваних концентрацій ( $\left.b=1,0031, S_{b}=0,0007816, a=-0,11, S_{a}=0,07891, S_{0}=0,03055, r=1,0000\right)$. Доведено, що запропонована методика характеризується достатньою збіжністю і правильністю у всьому діапазоні концентрацій $\left(\Delta_{\mathrm{z}}=0,06, \delta \%=0,2\right)$. Внутрішньолабораторну прецизійність підтверджено тим, що величина відносного довірчого інтервалу для п'яти паралельних визначень однієї серії препарату задовольняє критерію прийнятності $\left(\Delta_{z}=0,22 \% \leq 1,6 \%\right)$. За 
результатами визначення валідаційних характеристик методик кількісного визначення обгрунтовано та експериментально доведено, що дана аналітична методика може бути коректно відтворена, дає достовірні результати та придатна для аналізу таблеток ніфедипіну. У процесі верифікації методики кількісного визначення ніфедипіну в таблетках були вивчені валідаційні характеристики хроматографочної методики: правильність, лінійність, прецизійність, специфічність та внутрішньолабораторна прецизійність. Валідаційні характеристики методики не перевищують критичного значення похибки $(1,6 \%)$ i характеризуються якісними аналітичними показниками. Ця методика може бути коректно відтворена в умовах лабораторій з контролю якості лікарських засобів.

\section{ВЕРИФИКАЦИЯ ВЭЖХ МЕТОДИКИ КОЛИЧЕСТВЕННОГО ОПРЕДЕЛЕНИЯ НИФЕДИПИНА}

\section{В ТАБЛЕТКАХ}

И.Л.Комарицкий, В.А.Ханин, Н.Ю.Бевз, В.А.Георгияни

Ключевые слова: нифедипин; верификация; ВЭЖХ

В настоящее время в Украине зарегистрировано большое количество воспроизведенных лекарственных средств (ЛС). Преимущество воспроизведенных ЛС заключается в относительно невысокой стоимости по сравнению с оригинальным ЛС, поскольку создание и регистрация воспроизведенного ЛС требуют меньшего объема исследований и, соответственно, меньших материальных затрат на разработку, исследование и внедрение на рынок нового ЛС. В связи с созданием второго издания ГФУ и включением в неё статей на готовые лекарственные средства мы поставили себе целью проанализировать валидационные характеристики методики количественного хроматографического определения нифедипина в таблетках и провести её верификацию. Линейность методики определяли в пределах 80-120\% от номинальной концентрации. Линейность методики подтверждается во всем диапазоне исследуемых концентраций $\left(b=1,0031, S_{b}=0,0007816, a=-0,11, S_{a}=0,07891, S_{0}=0,03055\right.$, $r=1,0000)$. Доказано, что предложенная методика характеризуется достаточной сходимостью и правильностью на всем диапазоне концентраций $\left(\Delta_{z}=0,06, \delta \%=0,2\right)$. Внутрилабораторная прецизионность подтверждена тем, что величина относительного доверительного интервала для пяти параллельных определений одной серии препарата удовлетворяет критерию приемлемости $\left(\Delta_{z}=0,22 \% \leq 1,6 \%\right)$. Таким образом, по результатам определения валидационных характеристик методик количественного определения обосновано и экспериментально доказано, что данная аналитическая методика может быть корректно воспроизведена, даёт достоверные результаты и пригодна для анализа таблеток нифедипина. В процессе верификации методики количественного определения нифедипина в таблетках были изучены валидационные характеристики хроматографической методики: правильность, линейность, прецизионность, специфичность и внутрилабораторная прецизионность. Валидационные характеристики методики не превышают критического значения погрешности $(1,6 \%)$ и характеризуются качественными аналитическими показателями. Данная методика может быть корректно воспроизведена в условиях лабораторий контроля качества лекарственных средств. 